\title{
ORTA GELİR TUZAĞI: DİNAMİK PANEL VERİ ANALİŻi²
}

Hicran KASA ${ }^{3}$

\begin{abstract}
Öz
"Orta Gelir Tuzağı” kavramı, sürdürülebilir ekonomik büyümeyi başaramamış ve aynı kişi başına düşen milli gelir seviyesinde çok uzun yıllar takılı kalmış ülkeleri nitelendirmektedir. Bu çalışmada, seçilmiş OECD ülkelerine yönelik; Ar-Ge harcamaları, yurtiçi tasarruf oranları ve yüksek teknoloji ürün ihracatının ekonomik büyüme üzerine etkileri araştırılmıştır. Söz konusu değişkenler, dinamik CCEGM modeli kullanılarak analiz edilmiştir. 20 OECD ülkesinin 19952015 verilerinden yola çıkılarak oluşturulan panel veri sonucunda, beklentiye uygun olarak değişkenler arası pozitif sonuçlar elde edilmiştir. Ayrıca, söz konusu 20 ülkenin büyüme performanslarında en yüksek etkiye sahip olan değişken Ar-Ge harcamaları iken Türkiye özelinde değerlendirildiğinde en yüksek etkiye sahip değişkenin yurtiçi tasarruflar olduğu sonucuna varılmıştır. Bu bağlamda, Türkiye gibi orta gelirli ülkelerde Ar-Ge harcamalarının artırılmasına yönelik yapılacak yatırımların, uzun dönemde katma değeri yüksek mal ve hizmet üretimini ve ihracatını artıracağı gerçeğinden yola çıkarak öncelikli olarak yurtiçi tasarrufları artırmaya yönelik politikalara önem verilmelidir.
\end{abstract}

Anahtar Kelimeler: Orta Gelir Tuzağı, CCEGM, OECD, Türkiye, Dünya Bankası

1 Makalenin Geliş Tarihi: 21.2.2019

Makalenin Kabul Tarihi: 10.6.2019

$2 \mathrm{Bu}$ makale Hicran KASA tarafından hazırlanmış ve Doç. Dr. Volkan ALPTEKiN danışmanlığında 2018 yılında Celal Bayar Üniversitesi, Sosyal Bilimler Enstitüsü tarafından "Tasarruf Açığı ve Ar-Ge Harcamalarının Orta Gelir Tuzağına Etkileri: Seçilmiş OECD Ülkeleri Analizi” başlı̆̆g ile kabul edilen Doktora tezinden üretilmiștir.

3 Dr. Öğr. Üyesi, Türk Hava Kurumu Üniversitesi. e-mail: hkasa@thk.edu.tr, hicrankasa@ hotmail.com

Atıf: Kasa, H. (2019). Orta gelir Tuzağı: Dinamik panel veri analizi. Tesam Akademi Dergisi, Türkiye Ekonomisi Özel Sayısı, 153-182. http://dx.doi.org/10.30626/ tesamakademi.584291 
Middle Income Trap: A Dynamic Panel Data Analysis

\begin{abstract}
The middle income trap describes countries that have not been able to accomplish sustainable economic growth and have been stuck in the level of income per capita for many years. In this study, countries located in OECD have been analyzed by using savings rate, R\&D expenditures and high technology export data and investigated effect on sustainable economic growth. The variables have been analysed by applying dynamic CCEGM model. Positive results have been obtained as expected. In addition, while variable of R\&D expenditures have highest impact on the growth performance of 20 countries, variable of domestic savings have highest impact on the growth performance of middle income countries such as Turkey. In this context, since investments to increase R \& D expenditures will affect growth in the long run, middle income countries should be produce priority policies aimed at increasing domestic savings.
\end{abstract}

Keywords: Middle Income Trap, CCEGM, OECD, Turkey, World Bank 


\section{Giriş}

Fransız İhtilali'nin 1789'da gerçekleşmesinin ardından Feodalizmden Kapitalizme doğru geçiş ile birlikte üretim sisteminde ve toplumsal yapıda, meydana gelen yapısal değişimler Modernizme geçiş olarak adlandırılmaktadır. Modernizme geçiş hareketi ile birlikte var olan zenginliğin üretimi, dağıtımı ve tüketiminin araştırılması İktisat Bilimini ortaya çıkarmış ve kapitalizmin temelleri bu dönemde atılmıştır. Avrupa'da 18. yüzyıl ikinci yarısından başlayarak 19. yüzyılı da içine alan dönemlerde bilimsel yöntem ve rasyonel düşünme tekniklerinin gelişmesi ile birlikte yeni buluşların ve teknolojik ilerlemelerin önü açllmıştır. Geleneksel üretim araçlarının terk edilerek buhar gücü ile çalışan makinelerin keşfi, üretim artışının sağlanmasında dönüm noktası olurken Avrupa'da sermaye birikiminin önemli ölçüde artmasına neden olmuştur.

18. Yüzyll'da temelleri atılan söz konusu süreç "Sanayi Devrimi” olarak adlandırılmaktadır. Etkileri Avrupa özelinde başlayarak bütün dünyayı kapsayan, Sanayi Devrimi ile ortaya çıkan diğer önemli sonuçlardan bazıları şu şekilde özetlenebilir; üretim artışı ile birlikte toplumsal refah seviyesinin yükselmesi, köyden kente göçün artması, sanayi kentlerinin ortaya çıkmasının getirdiği ișsizlik kavramının doğması, yașam koşullarının kısmen iyileşmesi ile birlikte ölüm oranlarının düşmesi ve nüfusun artışı, en önemli üretim faktörlerinden olan hammadde ve işlenmiş ürünlerin satışı için pazar bulamama sorununun ortaya çıkışı, sömürgeciliğin varoluşu ve devamında gelen savaşlardır.

Sanayi Devrimi ile değișen dünya ticaret hacmi, ekonomik dengeleri değiştirmiş, geçim ekonomisinden piyasa ekonomisine doğru evirilen ekonomik bir düzen ortaya çıkmıştır. Ekonominin en önemli sektörü olan sanayide yaşanan gelişmelerin refahı artırdığı bilinmekle birlikte sanayileşmiş ülkeler ile az gelişmiş ve gelişmekte olan ülkeler arasında "büyüme" kavramı yaygın olarak tartışılmaya başlanmıștır.

Fransız Devrimi ile ortaya çıkan yeni fikirleri ve kültürel değişimleri, sanayi devrimi ile ortaya çıkan teknolojik gelişmeler takip etmiş ve tarihsel süreçte yașanan bireysel ve toplumsal temelli gelișmeler, ülkelerin gelir grupları arasında yer değiștirmelerine neden olmuştur. Ekonomik kalkınma sürecinde tarıma dayalı birçok ekonomi, yaşanan gelişmelerle birlikte düşük gelirden, düşük orta gelire ve teknolojik gelişmelerle birlikte sanayileşme sürecini yakalamayı başaran birçok ekonomi ise sırasıyla yüksek orta gelirli gruptan yüksek gelirli ülkeler grubuna evirilmiştir. Fakat bu süreçte her ekonominin zamana bağlı olarak aynı 
aşamaları geçirmesi beklenmemekle birlikte bazı ülkelerin çok uzun yıllar aynı gelir grubunda kaldığı gözlenmektedir. Smith (1994), Parent ve Prescott (1994) çalışmalarında, gelir grupları ve ekonomik büyüklüklerin ülkeden ülkeye farklılık göstermesinin temelinde, sahip olunan teknoloji, nitelikli işgücü, doğal kaynaklar ve olmazsa olmaz ekonomik ve siyasi istikrarın yer aldığını vurgulamışlardır.

20. yüzyıla gelindiğinde, ülkelerin sürdürülebilir ekonomik büyümeyi sağlayabilmelerinde teknolojik gelişmelerle desteklenen sanayileşme politikalarının yetersiz kaldığı, bu nedenle endüstriyel toplum (Sanayi Toplumu) yapısından bilgi toplumuna (Bilgi Toplumu) doğru bir geçişin olduğu görülmektedir. Ancak, küresel rekabetin gerisinde kalan; inovasyona yönelik politikalar üretemeyen, inovasyon yaratmaya yönelik yatırımlar yapmakta zorlanan, dolayısıyla enformasyon ve iletişim teknolojilerinin gerisinde kalan az gelişmiş ve gelişmekte olan ülkeler, sürdürülebilir ekonomik büyümeyi sağlayamamakta ve kişi başına düşen gelir seviyesinde sıkışıp kalmaktadırlar.

Orta gelirli ülkelerin, üst gelir grubuna dahil olan ülkelerin, büyüme performanslarına uyum sağlamakta zorlanmaları ve küreselleşen dünyanın hızlı ekonomik değişim ve dönüșümlerine entegre olamamaları olarak tanınabilecek "Orta Gelir Tuzağı (OGT)” kavramı, literatürde farklı yaklaşımlar ve tanımlarla yer almaktadır. Bunlardan en dikkat çekenleri ise Orta Gelir Tuzağı kavramını ilk olarak ortaya atan Dünya Bankası uzmanları Kharas ve Gill'e ait tanımlamadır. Kharas ve Gill tarafından 2007 yılında yayınlanan "Bir Doğu Asya Rönesansı: Ekonomik Büyüme için Fikirler" başlıklı rapora göre; Orta Gelir Tuzağ'ına yakalanan ülkeler, az gelişmiş ülkeler ile düşük ücretli standart imalat sanayi ürünlerinde rekabet edemeyen, diğer taraftan inovasyon temelli büyüyen üst gelir grubu ülkeleri yakınsamakta ise zorlanan ülkeler olarak tanımlanmaktadır (Gill,2007, s. 153). 


\section{Tablo 1}

\section{Ülkelerin Sinıflandırılması}

\begin{tabular}{|l|l|c|}
\hline Ekonomiler & $\begin{array}{l}\text { Kişi başına yıllık or- } \\
\text { talama gelir (\$) }\end{array}$ & Ülke Sayıları \\
\hline Düşük gelirli ekonomiler & 1,005 doların altı & - \\
\hline Orta gelirli ekonomiler & $\begin{array}{l}1,006-12,235 \text { dolar } \\
\text { arası }\end{array}$ & 109 \\
\hline Alt orta gelirli ekonomiler & $\begin{array}{l}1,006-\$ 3,955 \text { dolar } \\
\text { arası }\end{array}$ & 53 \\
\hline Üst orta gelirli ekonomiler & $\begin{array}{l}3,956-12,235 \text { dolar } \\
\text { arası }\end{array}$ & 56 \\
\hline Yüksek gelirli ekonomiler & 12,236 dolar ve üzeri & 78 \\
\hline
\end{tabular}

Kaynak: World Development Report 2018, http://data.worldbank.org (Erişim Tarihi 03.27.2018).

Tablo 1'de atlas metodu ${ }^{4}$ kullanılarak hesaplanmış kişi başına düşen milli gelir seviyeleri yer almaktadır. Ayrıca burada ifade edilen kişi başına düşen gelir ülkelerarası nominal kur düzeyini ve fiyatları da dikkate alan satın alma gücünün paritesine (SAGP) dayanarak belirlenmektedir. Reel döviz kurunun sabit bir ortalama düzeyinde hareket etmesini gerektiren bu durum nominal fiyatların deflate edilmesi ile daha anlamlı bir hal almaktadır (Taner, 2017, s. 265-280). Böylece SAGP yardımıyla hesaplanan kişi başına gelir ile birlikte reel kurun denge düzeyinden sapması da bir anlamda giderilmiş olmaktadır (Yilmaz, 2018, s. 427450). Nihayetinde ülkeler belirli kategorilere ayrılmış ve her bir üst gelir grubuna geçiş için eşikler oluşturulmuştur. Söz konusu eşiklere istinaden, orta gelir tuzağı ekonomilerin belirli bir kişi başına düşen gelir seviyesinde sıkışıp kalmaları $(1,006 \$-12,235 \$)$, uzun yıllar bu gelir grubundan üst gelir grubuna geçememeleri olarak adlandırılabilir. Bir diğer ifadeyle orta gelirli ülkeler, teknoloji yoğun sektörlerde baskın olan yenilikçi zengin ülkeler ile olgun endüstrilerde baskın olan düşük ücretli yoksul ülkeler arasında sıkışıp kalmışlardır. Bunun nedeni, düşük gelirli ekonomilerin emek yoğun sektörlerde karşılaştırmalı bir üstünlüğe sahip olmaları, yüksek gelirli ekonomilerin ise sermaye yoğun ve teknoloji yoğun

4 Belirli operasyonel ve analitik amaçlar için ABD doları cinsinden gayri safi milli gelirin hesaplanmasında, Dünya Bankası basit döviz kurları yerine Atlas dönüşüm katsayısını kullanır. Atlas dönüşüm faktörünün amacı, ulusal gelirlerin ülkeler arası karşıllaștırılmasında döviz kuru dalgalanmalarının etkisini azaltmaktır. Herhangi bir yıl için Atlas dönüşüm faktörü, bir ülke için o yılki döviz kurunun ortalaması ve önceki iki yıla ait döviz kurunun ortalamasıdır. 
sektörlerde karşılaştırmalı bir üstünlüğe sahip olmalarıdır.

Bu çalışmanın amacı; orta gelir tuzağının tespitinden ziyade, nedenlerinin araştırılması ve Türkiye'nin sürdürülebilir ekonomik büyümesini sağlayabilmesinde gerekli reformların neler olabileceğine yönelik önerilerin geliștirilmesidir. İlgili literatür incelendiğinde, $\mathrm{Ar}-\mathrm{Ge}$ ve inovasyona yönelik (yüksek teknolojili ve katma değeri yüksek ürün üretimi için) olarak yapılan yatırımların OGT' den çıkışta ve gelişmiş ülkeleri yakınsamakta etkin olduğu ve genellikle Asya Kaplanları olarak adlandırılan; Güney Kore, Tayvan, Hong Kong, Singapur, Tayland ve Malezya örnekleri üzerinde çalışmalar yapıldığı gözlemlenmektedir. Ayrıca, bu çalışmalarda orta gelir tuzağında yer alan ülkelerin temel sorunları arasında yer alan tasarruf açığına dolayısıyla Ar-Ge ve Inovasyona yönelik yatırımların finansman kaynağı olan yurtiçi tasarrufların önemine yeterince değinilmediği ve OECD ülkelerine yönelik yapılan çalışmaların eksikliği nedeniyle bu çalışma literatüre yeni bir bakış açısı kazandıracaktır. Bu bağlamda; çalışmanın ilk bölümünde orta gelir tuzağına ilişkin güncel literatüre yer verilmiştir. İkinci bölümde OGT'nin nedenleri ve tuzaktan çıkmayı başarmış ülke örnekleri değerlendirilmiștir. Çalışmanın son bölümünde ise Türkiye'nin ve diğer OECD ülkelerinin verileri ile yeni nesil panel veri modeli olan Dinamik Ortak Korelasyon Etkileri Grup Tahmincisi (CCEGM) kullanılarak ele aldığımız bağımsız değişkenlerin büyüme üzerine etkileri ampirik olarak gözlemlenmiştir. Böylelikle orta gelir tuzağını uzun yıllar deneyimlemiş Türkiye için geleceğe yönelik atılması gereken adımlar incelemiş olup, Türkiye'nin orta gelirden yüksekgelirli ülkeler seviyesine ulaşabilmesinde tasarrufları artırıcı önlemlere, yenilik odaklı üretimi artırıcı ekonomik reformlara ve nitelikli insan gücü yetiştirmede eğitimin önemine vurgu yapılmıştır.

\section{Literatür Özeti}

OGT kavramının dünya bankası sınıflandırmasından yola çıkarak ele alındığı bu çalışmada konu ile ilgili yapılmış "Betimsel" ve "Ekonometrik" literatür incelenmiş bunun yansıra güncel yayınlara da yer verilmiștir. Betimsel literatür genellikle Dünya Bankası (2012)'nin ülkeler arasındaki kıyaslamalarını ve ayrıca Hill ve dğ. (2012), Agénor ve El Aynaoui (2015), tarafından hazırlanan daha spesifik ülke çalışmalarını kapsamaktadır. Dünya Bankasıına (2012)'ye göre, 1960'tan 2008 yllına kadar 101 orta gelirli ekonomiden sadece 13 tanesi üst gelir grubuna geçmiştir. Bunlar sirasıyla; Ekvator Ginesi, Yunanistan, Hong Kong, İrlanda, İsrail, Japonya, Mauritius, Portekiz, Porto Riko, Singapur, Güney Kore, 
İspanya ve Tayvan'dır. Bu başarılarının arkasında ise emek yoğundan, elektronik parça imalatı ve montajı gibi tamamlayıcı mal üretimine geçişler yatmaktadır. Böylelikle uzmanlaştıkları alanlara yönelik mal ve hizmet ticareti artan bu ülkeler, lider konuma geldikleri söz konusu alanlarda artan ihracat gelirleri ile birlikte orta gelir tuzağından çıkmayı bașarmıșlardır. Ancak; Latin Amerika, Orta Doğu ve Kuzey Afrika'daki çoğu ülke, 1960 ve 1970’lerde orta gelir düzeyine ulaşmış ve günümüze kadar aynı gelir seviyesinde kalmışlardır.

Malezya ve Tayland gibi orta gelir tuzağını karakterize eden ülkeler bazı alanlarda başarılı olsalar da (Malezya Eğitim gibi) büyüme seviyelerinde yıllar içinde herhangi bir değişiklik olmamıştır. Aksine Çin, Hindistan, Vietnam ve Kamboçya gibi düşük emek veya hammadde maliyetleri ile üretim yapan ekonomilere karşı azalan rakabet gücü günümüze gelindikçe bu ülkelerin büyüme oranlarının gerilemesine neden olmuştur. Malezya ve Tayland gibi orta gelirli ekonomiler ihraç edilen mal yelpazesinde ve sanayi üretiminde ürün farklılaştırmasına gitmemeleri nedeniyle ayrıca zengin ülkelerin yenilikçi ve teknoloji yoğun ürettikleri mal ve hizmetlerle de rekabet edememeleri nedeni ile bu tuzakta yer almaktadırlar.

Güney Kore, Brezilya ve Türkiye gibi 1980 'lere kadar benzer büyüme oranlarına sahip ülkelerden, Güney Kore sürdürülebilir bir büyüme hızı yakalamayı başarmıştır. Inovasyona dayalı üretim ile ürün çeşitliliği sağlamayı ve belirli alanlarda uzmanlaşmayı sağlamayı başarmış Güney Kore nihayetinde üst gelir grubu ülkeler seviyesine ulaşmıștır.

Yapılan ekonometrik analizlerle ise orta gelir tuzağı kavramı daha nesnel bir alt yapıya oturtulmaya çalışılmıştır. Bu yapılan çalışmaların başlıcaları Eichengreen ve ark. (2012, 2014), Felipe ve diğ. (2012, 2014), Jimenez ve diğ. (2012), Aiyar ve ark. (2013), Im ve Rosenblatt (2013), ve Y. ve Robertson (2015)'a aittir.

Spence (2011) tarafından "orta gelir geçişi" olarak adlandırılan tuzak "bir ülkenin, kişi başına düșen gelirinin 5.000 ila 10.000 dolar aralığına ulaştığında gerçekleșen büyüme seviyesi" olarak tanımlamaktadır. Nitelik gerektiren mesleklerde artan ücretler nedeniyle küresel rakiplerinin ve endüstriyelleşme sürecinin gerisinde kalan ülkeler, daha düşük ücretli ülkelere yönelmekte ve değer yaratma yolunda daha fazla sermaye, beșeri sermaye ve bilgi yoğun üretim teknolojileri ile üretim yapan yeni sanayi grupları ile zaman içinde yer değiştirmektedirler (Spence, 2011). Ayrıca 1957'den başlayan uluslararası veriler kullanarak, hızlı büyüyen ekonomilerin büyüme hızlarındaki yavaşlamanın ne zaman başladığı ve 
nedenleri Çin'den yola çıkarak araştırılmıștır. Bu yavaşlama sürecinin tespitinin ise iki şekilde ortaya çıkabileceği kanaatine varılmıștır. İlki satın alma gücü paritesine (2005 sabit fiyat dolar) göre kişi bașına düșen gelirin 10.000 - 11.000 dolar aralığında iken ve ikincisi ise 15,000 -16,0000 dolar aralığına yaklaștığındadır. Orta gelirli ülkelerdeki yüksek büyümenin tek bir noktada değil de zaman içinde ikinci bir gelir seviyesinde de yaşanabileceği sonucuna varılmıştır. Söz konusu çalışmada, diğer ülkelere kıyasla yüksek teknoloji ürün ihracatının fazla olduğu ve nüfusun ikincil (orta öğretim) ve üçüncül (yükseköğretim) eğitim seviyesine sahip olduğu ülkelerin orta gelir tuzağından kaçınabildiği ve bu ülkelerdeki durağanlığın daha az olduğu gözlemlenmiştir (Eichengreen, 2013, s. 15).

Orta gelir tuzağı ile ilgili yapılan araştırmalarda, sürdürülebilir büyümenin sağlanabilmesinde "üretim yapısının, bilgi yoğun ve daha fazla katma değer yaratan faaliyetlere doğru giderek kaydığ 1 ekonomik ve sosyal dönüşüm sürecinin" gerekliliği ortaya çıkmıştır (Paus, 2012, s.115-138). Ekonomik ve sosyal dönüşüm sürecini gerçekleștiremeyen ülkelerin, bilgi yoğun ve katma değeri yüksek üretim yapan ülkelere karşı rekabet gücü azalacak ve belirli bir gelir grubunda sıkışıp kalacaklardır. Bu sıkışıklığın bir diğer ayrımı ise 1990 yılı satın alma gücü paritesi (PPP purchasing power parity)'ne göre yapılan sınıflandırmayla karşımıza çıkmaktadır. GSYİH dört gelir grubuna ayrılır: buna göre kişi başına düşen GSYH'si 2,000 doların altında olan ülkeler düşük gelir 2,000 ila 7,250 dolar arasında olan ülkeler alt-orta gelir 7,250 dolar ve 11,750 dolar arasında olanlar ise üst orta gelir grubundadır. Yüksek gelirli ülkeler sınıfı ise GSYH'si 11.750 dolar üzerinde olanlar ülkeler sınıfıdır. Ekonomide yapısal dönüşümler (düşük üretkenlik faaliyetlerinden yüksek üretkenlik faaliyetlerine doğru), ihraç edilen ürünlerin türleri (tüm ürünler büyüme ve gelişme için aynı sonuçlara sahip değildir) ve ekonominin çeşitlendirilmesi gibi faktörlerin, orta gelir tuzağındaki ülkelerin yüksek gelir gurubuna geçişinde gerekli olduğu sonucuna varılmışlardır (Felipe, 2012, s. 82).

Lewis (1954) modelindeki "dönüm noktası" kavramı ile faktör piyasalarında reel ücretlerin, ekonominin işgücü fazlasından, işgücü eksikliğine kaymasıyla birlikte yükseleceğini ileri sürmektedir. Büyüme için, ülkenin yüksek teknolojik gelişmelere ve yönetsel kaynaklarla donatılması ve sermayenin verimli kullanılması gerekmektedir. Başka bir deyişle, ekonominin büyümesi, artan oranda toplam faktör verimliliğine (TFP) dayanmaktadır. Faktör verimliliğinin artırabilmek için ihtiyaç duyulan nitelikli insan gücü yetiştiremeyen, yenilikçi politikalara ayak uyduramayan ve emek yoğun üretim sektörlerindeki hâkimiyetini kaybeden ülkelerin büyüme oranı Grafik 1'de gösterilen C-D yolunda 
durağanlaşır C-E yolunda ise bir tür sarmal olarak görülebilecek OGT ile karşı karşıya kalmaktadırlar (Tran, 2013, s.421).

\section{Grafik 1}

\section{Kişi Başına Düşen GSMH'a Göre Gelişim Süreci}

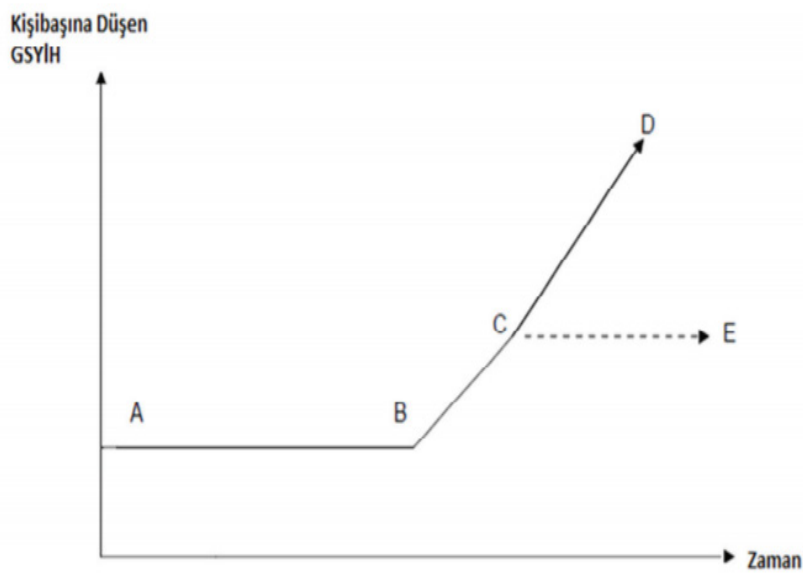

Kaynak: Tho, Asian Development Bank Imstitute.

A - B : Geleneksel toplum, az gelişmişlik, karşılaşılan yoksulluk tuzağı.

B - C : İlk gelişim aşaması, yoksulluk tuzağından kaçış, piyasaların ilk gelişim evresi.

C : Orta gelir seviyesi.

C - D : Yüksek gelir düzeyine (D’ye) ulaşmak için sürekli büyümeyi devam ettirmek.

C - E : Durgunluk veya düşük büyüme - orta gelirli tuzağı.

Orta gelir tuzağı tespitine ilişkin bir diğer çalışma ise Woo (2012) tarafindan hazırlanan "China meets the middle-income trap: the large potholes in the road to catching-up" adlı çalışmasında karşımıza çıkmaktadır. Yazar; Maddison Veri Tabanı'nı kullanarak oluşturduğu yakınsama endeksiyle, orta gelir tuzağındaki ülkelerin kişi başına gelir seviyelerinin ABD'nin kişi başına gelir seviyesinin yüzde 20'si ile yüzde 55’i arasında olduğunu (satın alma gücü paritesiyle düzeltilmiş ve 1990 yılı sabit fiyatları kullanılarak) varsaymaktadır. Yüksek gelirli ülkelerin kişi başına düşen milli gelirinin yüzde 55 'in üstünde ve düşük gelirli ülkelerin ise yüzde 20'nin altında olduğu belirtilerek bir sınıflandırma 
yapılmıştır.

Robertson ve Ye (2011), orta gelir tuzağının varlığını test etmek amacıyla 189 ülke için yaptıkları analizde, "Genişletilmiş Dickey ve Fuller Birim Kök Testi” kullanmışlardır. Böylece; orta gelir seviyesindeki ülkelerin kişi başına gelir seviyesindeki büyümenin durağanlığı test edilmiştir. Örneklemde yer alan ülkeler, ABD’nin kişi başına GSYH'sinin \%8 ila \%36'sı arasında yer olan ülkelerden oluşmaktadır. Bu aralıkta yer alan 46 ülkenin, zengin ekonomilerin kişi bașına düşen gelir düzeylerini yakınsamamaları orta gelir tuzağında olabileceklerini göstermektedir.

Son olarak, konu ile ilgili 2017-2018 yıllarını kapsayan güncel makaleler incelenmiştir. Güncel çalışmalar genel olarak tuzaktan çıkabilmek için ülkelerin yeni büyüme stratejileri, geliștirmeleri gerekliliğini ortaya koyarken, ihtiyaç duyulan yeni sanayi politikalarına, yapısal reformlara ve toplam faktör verimliliğini artırmada Ar-Ge faaliyetlerinin, demografik yapının önemine dikkat çekilmiștir.

1970yılı vesonrasındaÇin'de izlenen ekonomik reformlar sonucundabilim ve teknoloji merkezli yatırımlar artmış. Çin'in inovasyon politikalarında gerçekleşen kayda değer gelişim, ülkelerin orta gelir tuzağından çıkmasında geçmişte olduğundan daha farklı inovasyon politikalarının uygulanmasının gerekliliğini ortaya koyulmuştur (Liu ve ark., 2017, s. 656-669 ). Bu politikaların etkin olarak uygulanması gereken orta gelirli ülkelerdeki endüstriler, küresel teknoloji sınırına olan uzaklığına bağlı olarak beş farklı sınıfa ayrılabilir. Bunlar sırasıyla; yetişen endüstriler, önde gelen endüstriler, karşılaştırmalı avantaj-kaybeden endüstriler, kısa inovasyon döngüsü endüstrileri ve karşılaştırmalı üstünlüğe sahip stratejik sektörlerdir. Dolayısıyla sanayi politikalarının bu sınıflar göz önüne alınarak düzenlenmesi orta gelirli ekonomiler için önemlidir (Lin, J. Y., 2017, s. 5-18). Üretilen mal ve hizmet miktarı ve niteliği ile doğrudan bağlantılı olan sanayi politikaları, ülkelerin büyüme oranlarını dolayısıyla gelir grupları arasındaki geçişleri etkilemektedir. Bu nedenle düşük ve orta gelirli ülkelerin üst gelir gruplarına sıçrayabilmelerinde büyümeye etki eden faktörler farklılık göstermektedir (Bulman, D., Eden, M., and Nguyen, H. 2017, s. 5-28). Bu bağlamda Kim, J. ve Park, J. (2018) tarafından hazırlanan çalışmada 1975-2014 dönemi orta gelirli ekonomilerin büyüme oranlarının artmasında en önemli faktörlerin; insan sermayesi, etkin nüfus ve Ar-Ge harcamalarının artmasıdır. Diğer yapılan çalışmalarca orta gelir tuzağından çıkmada etkili olan faktörler Gore, C. (2017)'e göre kentleşme, Ha, J., ve Lee, S. H. (2016)'e göre düşük doğurganlık oranları ve beşeri sermayeye yönelik yatırımlar, Abiad, A. 
ve dğ. (2018)'e göre ise bilgi ve iletişim teknolojisine yönelik alt yapı çalışmalarına yapılan yatırımlar olduğu görülmektedir. Güncel çalışmalar, orta gelir tuzağının varlığının tespitinin aksine bu tuzaktan çıkışta hangi ekonomik faktörler üzerinde durulması gerektiğini göstermektedir.

Orta gelir tuzağının kavramına ilişkin betimsel ve istatistiksel çalışmaların geneline bakıldığında orta gelir tuzağının nedenleri; fiziksel sermayenin azalan getirisi, ucuz işgücünün azalması ve imitasyona dayalı üretim artışı, yeterli kalifiye işgücüne sahip olunamaması, fikri mülkiyet haklarının yeterince korunamaması, yanlış teşvikler ve gelişen altyapı yatırımlarına ve finans kaynaklarına uluşamamak, yatırımların temel finansman kaynağı olan yurtiçi tasarrufların yetersiz olması, Ar-Ge'ye yeterince önem verilmemesi şeklinde sıralanmaktadır.

Orta gelir tuzağı ve temelinde yatan ekonomik durgunluğun nedenlerinden yola çlkarak düşük orta gelir seviyesinden yüksek orta gelir seviyesine yükselmeyi başarmış ülkeler Tablo 3'de gösterilmektedir. 


\section{Tablo 3}

1950 Sonrasında Düşük Orta Gelir Seviyesinden Yüksek Orta Gelir Seviyesine Ulaşan Ülkeler

\begin{tabular}{|c|c|c|c|}
\hline Ülke & $\begin{array}{c}\text { Düşük Orta Gelir } \\
\text { Seviyesine Ulaştığı } \\
\text { Yıl }\end{array}$ & $\begin{array}{c}\text { Yüksek Orta } \\
\text { Gelir Seviyesin- } \\
\text { de Geçirilen Yıl } \\
(3,956-12,235 \\
\text { dolar arası) }\end{array}$ & $\begin{array}{c}\text { Orta Gelir } \\
\text { seviyesinde } \\
\text { geçirilen } \\
\text { süre }(3,956- \\
12,235 \text { dolar } \\
\text { arası) }\end{array}$ \\
\hline Taypei, Çin & 1967 & 1986 & 19 \\
\hline Çin & 1992 & 2010 & 18 \\
\hline Malezya & 1978 & 1995 & 17 \\
\hline Kore & 1978 & 1988 & 10 \\
\hline Tayland & 1971 & 2008 & 37 \\
\hline Bulgaristan & 1953 & 2006 & 53 \\
\hline Türkiye & 1975 & 2004 & 29 \\
\hline Kosta Rika & 1976 & 2003 & 27 \\
\hline Umman & 1975 & 1981 & 6 \\
\hline Brezilya & 1975 & 1996 & 21 \\
\hline Meksika & 1974 & 1993 & 19 \\
\hline $\begin{array}{l}\text { Türkmenis- } \\
\text { tan }\end{array}$ & 2000 & 2011 & 11 \\
\hline Azerbaycan & 2005 & 2009 & 4 \\
\hline Fiji & 1975 & 2008 & 33 \\
\hline Şili & 1971 & 1995 & 24 \\
\hline Kolombiya & 1979 & 2007 & 28 \\
\hline Peru & 1991 & 2010 & 19 \\
\hline Filipinler & 1995 & 2016 & 21 \\
\hline $\begin{array}{l}\text { St Vincent ve } \\
\text { Grenadinler }\end{array}$ & 1982 & 2003 & 21 \\
\hline Güney Afrika & 1973 & 2005 & 32 \\
\hline
\end{tabular}

Kaynak: Felipe, Abdon ve Kumar, 2012: 22 yola çıkarak yazar tarafından hazırlanmıştır. 
Buna göre düşük orta gelir seviyesinde en uzun süre kalan ülke Bulgaristan iken onu sırasıyla Tayland, Fiji, Güney Afrika, Türkiye takip etmektedir. Düşük orta gelir seviyesinde en az kalan ülkeler ise sırasıyla Azerbaycan, Umman, Kore ve Türkmenistan'dır. Tablo 3'te yer alan ülkeler 2017 itibariyle halen yüksek orta gelir seviyesinde yer alan ülkelerdir.

Orta gelir tuzağını kavramının var olup olmadığından ziyade, nedenlerinin ve çözüm önerilerinin tartışıldığı bu çalışmanın ilerleyen kısımlarında OECD ülkelerine yönelik ampirik analize yer verilmiștir. Böylelikle OECD içinde yer alan; orta gelirli ekonomilerin, yakın geçmişte Avrupa Birliğine katılmış olmanın sağladığı refah artışı ile üst gelir grubuna yükselmiş ekonomilerin ve sürdürülebilir ekonomik büyüme hedefini gerçekleștirmiş ekonomilerin kişi başına düşen gelirlerine bağımsız değişkenlerin etkileri incelenmiştir.

\section{Araștırmanın Amacı, Yöntemi, Veri Seti ve Bulgular}

Orta Gelir Tuzağı kavramının çok uzun yıllara dayanan bir geçmişi olmamakla birlikte sürdürülebilir ekonomik büyüme hedefi her ülke için her dönem varoluştur. Konu ile ilgili literatür değerlendirildiğinde yapılan çalışmaların genelinin Doğu Asya ülkelerine yönelik olduğu ve benzer faktörler (değişkenler) üzerine yoğunlaşıldığı gözlemlenmiștir. $\mathrm{Bu}$ nedenle ekonomik büyümenin sürdürülebilirliğinde en etkili faktörlerden olan inovasyonun temel göstergelerinden Ar-Ge harcamaları ve yüksek teknoloji ürün ihracatı verileri ayrıca gelişmekte olan ülkelerde yatırımların finansmanında kullanılan yurtiçi tasarruflar modele dahil edilmiştir.

Bu çalışmada; Türkiye'nin dâhil olduğu seçilmiş 20 OECD ülkesi için Panel Veri analizi uygulanmıștır. Analizde 1995-2015 dönemini kapsayan yıllık veriler kullanılmış ve bu veriler Dünya Bankası ve OECD veri tabanlarından derlenmiştir. Kullanılan veri setinin 1995 yılı ve sonrasındaki tarihlerden oluşmasının sebebi bu tarihten itibaren bütün ülkelere ait eşit verilere ulaşmasıdır.

Çalışmaya konu olan her bir ülkenin kişi başına düşen milli gelirlerine, Ar-Ge harcamaları, yurtiçi tasarruf oranları ve yüksek teknoloji ürün ihracatlarının etkileri araştırılmış, elde edilen sonuçlar seçilmiş 20 ülke için değerlendirilmiştir. Kullanılan Ar- Ge harcamalarına yönelik verilerin yıllık olarak yayınlanması nedeniyle diğer bağımsız değişkenler için de yıllık veri seti kullanılmıştır. Ar-Ge harcamaları Endüstri 4.0'ın yapı taşları olan inovasyon ve teknolojik gelişmeler üzerinde etkin 
olduğundan bu yolla verimlilik dolayısıyla OGT'ye etkisi üzerine çlkarımlarda bulunulmuștur. Yine benzer bir amaçla değişen istek ve ihtiyaçların karşılanmasında Ar-Ge harcamaları ile desteklenen yüksek teknoloji ürün ihracatının etkileri irdelenmiştir. Bu çalışmada ileri teknoloji ürünlerden elde edilen ihracat gelirlerinin ekonomik büyümeye etkisi dikkate alınmıștır. Aynı ekonomik ișbirliğine üye ülkeler üzerine yapılan bu araştırmada kullanılan yüksek teknoloji ürün ihracatı verileri, OECD kriterlerine göre sınıflandırılmış yüksek teknolojili ürünlerine yöneliktir. Ancak yıllar itibariyle değişen yüksek teknoloji ürün miktarı ve ülke ekonomisine getirisi farklı sınıflandırma yöntemlerinde farklı sonuçlar doğurabilecektir. Ayrıca, gelișmekte olan ülkeler için büyük önem arz eden yatırımların iç finansmanla desteklenmesi ve etkilerinin gözlemlenmesi açısından yurtiçi tasarrufların da modelde yer alması uygun bulunmuştur.

Modele konu olan başlıca ülkeler; Türkiye, Amerika, İtalya, Güney Kore, Almanya, Fransa, İzlanda, Danimarka, Avusturya, İsrail, Kanada, İngiltere, Çek Cumhuriyeti, Macaristan, Polonya, Yunanistan, Letonya, Slovakya, Portekiz ve Japonya șeklinde sıralanmaktadır. Bu analizde kişi başına düșen GSYH'nin doğal logaritması bağımlı değişken olarak kullanılmaktadır. Bağımsız değişken olarak Ar-Ge Harcamalarının GSYH'a oranın doğal logaritması, Yurtiçi tasarrufların doğal logaritması ve Yüksek Teknoloji İhracatı verilerinin doğal logaritması kullanılmıștır.

Yeni nesil panel veri modellerinde, geleneksel modellerden farklı olarak yatay kesitlerde bağımlılık olması ve eğim katsayılarının homojen olmaması (slope heterogenaity) durumları dikkate alınmakta ve modeller gerçeğe daha da yaklaşabilmektedir. Bu sebeple çalıșmada önce yatay kesit bağımlılığı analiz edilmektedir. Yatay kesit bağımlılığının tespit edildiği panel veride yatay kesit bağımlılığını dikkate alan ikinci nesil panel birim kök ve eşbütünleşme testleri yapılmıștır. Ardından eğim katsayılarının homojenliği test edilmiş, eğim katsayıları hetorejen bulunarak hem yatay kesit bağımlılığını hem de eğim katsayı heterojenliğini dikkate alan yeni nesil Panel Data modeli olan Dinamik CCEGM (Cross-Correlated Effects Mean-Group Estimator) Modeli kullanılmıştır. Eğim katsayılarının heterojen olması modelde kullanılan değişkenler arasında yakın ve benzer ilişkiler olmadığının göstergesidir. Başka bir ifadeyle eğim katsayılarının heterojen olması, hem Ar-Ge yoğun ileri teknoloji ürün ihracatının hem de Ar-Ge harcamalarının modele dahil edilmesinde sonuçların güvenilirliğinde her hangi bir sorun olmayacağının göstergesidir. Așağıda Tablo 4'te kullanılan verilerin tanımlayıcı istatistikleri sunulmaktadır. 


\section{Tablo 4}

Tanımlayıcı İstatistikler

\begin{tabular}{|l|c|c|c|c|c|}
\hline \multicolumn{1}{|c|}{ Değişken } & $\begin{array}{c}\text { Göz- } \\
\text { lem }\end{array}$ & Ortalama & $\begin{array}{c}\text { Std. Sap- } \\
\text { ma }\end{array}$ & Min & Max \\
\hline $\begin{array}{l}\text { LGDP (Kişi } \\
\text { Başına Düşen } \\
\text { GDP- Logarit- } \\
\text { ma) }\end{array}$ & 420 & 9.931867 & 0.759317 & 7.753311 & 11.13237 \\
\hline $\begin{array}{l}\text { LRD (Ar-Ge } \\
\text { Harcamala- } \\
\text { ri-Logaritma) }\end{array}$ & 420 & 0.367781 & 0.667972 & -1.287354 & 1.487948 \\
\hline $\begin{array}{l}\text { LGDS (Yurtiçi } \\
\text { Tasarruf- } \\
\text { lar-Logarit- } \\
\text { ma) }\end{array}$ & 420 & 25.17225 & 1.857432 & 20.22275 & 28.77781 \\
\hline $\begin{array}{l}\text { LHTE (Yüksek } \\
\text { Teknoloji İh- } \\
\text { racatı -Loga- } \\
\text { ritma) }\end{array}$ & 420 & 22.78112 & 2.252061 & 17.11371 & 26.12091 \\
\hline
\end{tabular}

Ar-ge Harcamaları, Yurtiçi Tasarruflar ve Yüksek Teknoloji İhracatına dayalı büyüme hipotezini test etmek için (1) numaralı denklemde sunulan model kullanılmıştır:

$$
\begin{aligned}
& \operatorname{LGDP}_{\text {it }}=\lambda_{i} d_{-} t+\alpha_{1 i} \operatorname{LRD}_{i t}+\operatorname{LGDS}_{i t}+\operatorname{LHTE}_{\text {it }}+u_{i t} \\
& u_{i t}=\theta_{i} f_{t}+\varepsilon_{i t} \quad i=1,2, \ldots, N \text { and } t=1,2, \ldots T
\end{aligned}
$$

Denklemde LGDP, kiși bașına düșen GSYH'nın logaritmasını, LRD Ar-Ge harcamalarının logaritmasını, LGDS Yurtiçi tasarrufların logaritmasını ve LHTE ise Yüksek teknoloji ihracatı verilerinin logaritmasını, dt ve ft ise gözlemlenen ve gözlemlenemeyen ortak etkileri ve ise $\varepsilon_{\mathrm{it}}$ hata terimini göstermektedir.

Uygulamalı analizde ilk önce seriler arasında yatay kesit bağımlılığı olup olmadığı araştırılmıştır. Yatay kesit bağımlılığını analiz etmek için, Peseran (2004) tarafından önerilen CD testi ve yine Peseran ve ark., (2008) tarafından önerilen yanlılığı düzeltilmiş LM testi (Bias adjusted LM test) kullanılmıştır. Serilerde yatay kesit bağımlılı̆̆ı bulunduktan sonra, yatay kesit bağımlılığı dikkate alan ikinci nesil birim kök testi olan Peseran (2007) tarafından önerilen CIPS birim kök testi kullanılmıștır. 
Serilerin birinci mertebeden durağan yani I(1) oldukları bulunduktan sonra seriler arasındaki eş bütünleşme ilişkisi yine yatay kesit bağımlılığını dikkate alan ikinci nesil birim kök testi olan Westerlund (2008) tarafından önerilen Durbin Hausman eș bütünleșme testi kullanılarak analiz edilmiştir. Durbin Hausman testi yatay kesit bağımlılığını dikkate almak için panel (DHp) ve grup (DHg) olmak üzere iki testten oluşmaktadır. Temel hipotez eş bütünleşme olmaması biçiminde kurulmaktadır. DHp testinde otoregresif parametrelerin tüm yatay kesitler için aynı olduğu varsayllırken, DHg testinde otoregresif parametrelerin yatay kesitler arasında değișebileceği varsayılmaktadır.

Seriler arasında eş bütünleşme ilişkisi bulunduktan sonra Pesaran ve Yamagata (2008) tarafından önerilen eğim heterojenliği testi kullanılarak eğim heterojenliği olup olmadığı test edilmiştir. Birinci nesil panel veri modellerinde eğimin homojen olduğu varsayılmaktadır. Eğer bu doğru değilse geleneksel panel veri tahmincileri yanlı olabilecektir. Yatay kesit ve zaman boyutu geniş olan panellerde eğim genellikle homejen değildir (Pesaran and Smith, 1995, s. 79-113; Im ve ark., 2003, s. 53-74).

Eğim heterojenliği testi sonucu eğim heterojenliği bulunduğu için hem yatay kesit bağımlılı̆̆ını hem de eğim heterojenliğini dikkate alan bir tahminci olan Peseran ve Chudik (2015) tarafından geliștirilen Dinamik Ortak Korelasyon Etkileri Grup Tahmincisi (Dynamic Common Correlation Effects Mean Grup Estimator) modeli kullanılmıştır. Ortak Korelasyon etkileri grup tahmincisi CCEGM modeli ilk olarak Peseran (2006) tarafından önerilmiştir ve Kapatinos ve ark,. (2011) tarafından geliştirilmiştir. CCEGM modelinin dinamik versiyonunda modele açıklayıcı değişken olarak gecikmeli bağımlı değişkenin yanında yatay kesit ortalamalarının gecikmeleri de eklenmiștir. Peseran ve Chudik (2015)'te yeterli sayıda yatay kesit ortalamasının gecikmesi modele eklenirse dinamik CCEGM modelinin daha başarılı olduğu gösterilmiştir. Dinamik CCEGM modeli yatay kesit bağımlılı̆̆ ve eğim homojenliğinin yanında yapısal kırılma ve durağan olmayan gözlemlenemeyen ortak faktörler durumlarında da daha başarılı sonuçlar vermektedir.

Dinamik CCEGM modeli aşağıdaki denklemde gösterildiği şekilde kurulmaktadır.

$$
\mathrm{y}_{\mathrm{it}}=\alpha_{0 \mathrm{i}} \mathrm{y}_{(\mathrm{it}-1)}+\alpha_{1 \mathrm{i}}+\beta_{\mathrm{i}} \mathrm{x}_{-} \mathrm{it}+\sum_{(\mathrm{i}=1)}^{\mathrm{n}} \delta_{-} \mathrm{i} \overline{\mathrm{y}}_{(\mathrm{it}-\mathrm{j})}+\sum_{(\mathrm{j}=1)}^{\mathrm{n}} \theta_{\mathrm{i}} \overline{\mathrm{x}}_{(\mathrm{it}-\mathrm{j})}+\varphi_{\mathrm{i}} \mathrm{f}_{\mathrm{t}}+\varepsilon_{\mathrm{it}}
$$

Denklemde $y_{\text {it }}$ bağımlı değişkeni, $\alpha_{1 \mathrm{i}}$ gruplar arasında zamanla değişmeyen heterojenliği yakalayan grup sabit etkilerini, $x_{i t-i}$ ve $y_{(i t-1)}^{-}$açılklayıcı 
değişkenler vektörünü, ve gecikmeli yatay kesit ortalamalarını, $\beta_{i}$ gözlemlenen değişkenlerin ülke spesifik eğimlerini, $f_{t}^{5}$ ise $\phi_{i}$ heterojen faktörü ile gözlemlenemeyen ortak faktörleri ve cit hata terimini göstermektedir.

\section{Lagrange Multiplier LM Test ve CD Testi Sonuçları}

Lagrange Çarpanı (LM) testi olasılık çerçevede yer alan parametreler hakkında geliştirilen hipotezleri test eden genel bir prensiptir. Test edilen hipotezler parametrelerin değerleri üzerindeki bir veya daha fazla kısıt olarak ifade edilir. Bir LM testi yapmak için, kısıtlamalara tabi parametrelerin tahmini yapılması gereklidir. Bu durum, hem sınırlı (kısıtlı) hem de sinırsız tahminler gerektiren olabilirlik oranı testlerine (likelihood ratio tests) ve sinırlanmamış tahminlere dayanan Wald Testleri ile tezattır.

Yatay kesit bağımlılı̆̆ının varlı̆̆ı, panelin zaman boyutu yatay kesit boyutundan büyük olduğunda Breusch-Pagan (1980) Lagrange Multiplier (LM) testiyle; her ikisi de büyük olduğunda Pesaran (2004) Cross-Section Dependence (CD) testiyle araştırılabilmektedir. Breusch And Pagan (1980) LM Testi; panel veri analizinde, tesadüfi etkiler modelinin mi yoksa klasik modelin mi havuzlanabilir (pooled) kurulması gerektiğini anlamak için kullanılır. Test istatistiği;

$$
L M=\frac{n T}{2(T-1)}\left\{\frac{\sum_{i=1}^{n}\left[\sum_{t=1}^{T} e_{i t}\right]}{\sum_{i=1}^{n} \sum_{t=1}^{T} e_{i t}{ }^{2}}\right\}^{2}=\frac{n T}{2(T-1)}\left\{\frac{\sum_{i=1}^{n}\left[T \bar{T}_{i t}{ }^{2}\right]}{\sum_{i=1}^{n} \sum_{t=1}^{T} e_{i t}{ }^{2}}-1\right\}
$$

H0: $\sigma 2 u=0$

$H 1: \sigma 2 u \neq 0$,

Burada boş hipotez, veri setinin klasik model ile kurulabileceğini ifade ederken, alternatif hipotez ise, klasik model ile kurulamayacağını ifade etmektedir (Baltagi ve Lí, 1990, s. 103-107).

\section{Cross-Sectional Dependence (CD-Test)}

CD Test istatistikleri Pesaran (2004) tarafından geliştirilmiş olup aşağıdaki gibidir:

Bu çalışmanın boş hipotezi yatay kesit bağımlılığı olmadığıdır. Ayrıca, CD $\rightarrow \mathrm{N}(0,1)$ fonksiyonunun limiti $\mathrm{N} \rightarrow \infty$ ve T yeterince büyükse geçerlidir.

$5 \mathrm{ft}$, eşzamanlı olmayan ve doğrusal olmayan, eșbütünleșme için izin verebilir. 
LM istatistiği farklı olarak, $\mathrm{T}$ ve $\mathrm{N}$ değerleri sabit olduğunda; $\mathrm{CD}$ istatistik ortalaması, heterojen, durağan olmayan ve dinamik modeller dahil olmak üzere panel veri modelleri için sıfırdır (De Hoyos and Sarafidis, 2006, s. 482-496).

$$
\mathrm{CD}=\frac{\sqrt{2 T}}{\sqrt{N(N-1)}}\left(\sum_{i=1}^{N-1} \sum_{j=i+1}^{N} p i j\right)
$$

Seriler arasında yatay kesit bağımlılığı olması durumunda sonuçlarda önemli ölçüde sapmalar meydana gelmekte, en küçük kareleri temel alan tahminciler etkin olmamaktadır. Bu sebepten, birim kök ve eşbütünleşme literatürüne yatay kesit bağımlılığını dikkate alan yöntemler kazandırılmıștır. Yatay kesit bağımlılığını sınayan ilk test Breusch Pagan (1980) CDLM testidir. İlgili literatür Pesaran (2004) ve Pesaran ve ark. (2008) tarafından geliştirilen testler ile devam etmiştir. Grup ortalamasının sıfır bireysel ortalamaların sıfırdan farklı olması durumunda CDLM testinin sapmalı olması dolayısıyla Pesaran, Ullah ve Yamagata (2008) test istatistiğine varyansı ve ortalamayı eklemek suretiyle CDLM $_{\text {adj }}$ testini elde etmişlerdir. İlk şekli aşağıdaki gibi olan test;

$$
C D L M=\mathrm{T} \sum_{i=1}^{N-1} \sum_{j=i+1}^{N} \hat{p}_{i j}^{2} \sim \frac{X_{N(N-1)}^{2}}{2}
$$

Daha sonra test istatistiğine varyans ve ortalamanın da eklenmesiyle aşağıdaki hali almıştır (Pesaran ve ark,. 2008);

$$
C D L M_{a d j}=\left(\frac{2}{N(N-1)}\right) \sum_{i=1}^{N-1} \sum_{j=i+1}^{N} \hat{p}_{i j}^{2} \frac{(T-K-1) \hat{p}_{i j}-\hat{\mu}_{T i j}}{v_{T i j}} \sim N(0,1)
$$

Testin hipotezleri ise aşağıdaki şekildedir:

$\mathrm{H}_{0}$ : Yatay kesit bağımlılı̆̆ yoktur,

$\mathrm{H}_{1}$ : Yatay kesit bağımlılığı vardır.

Test sonucunda $\mathrm{H}_{0}$ hipotezinin reddedilmesi paneli oluşturan birimler arasında yatay kesit bağımlılığı olduğunu göstermektedir.

Bu çalışmada 20 ülke ve 20 (1995-2015) yll olduğu için LM testi kullanılmıştır. Ancak bu test, grup ortalaması sıfır ve bireysel ortalama sıfırdan farklı olduğunda sapmalı olmaktadır. Pesaran ve ark,. (2008) bu sapmayı, test istatistiğine varyansı ve ortalamayı da ekleyerek düzeltmiştir. Bu nedenle testin ismi sapması düzeltilmiş LM testi (LMadj) 
olarak ifade edilmektedir. Yatay kesit bağımlılı̆̆ı test sonuçları Tablo 5'de sunulmaktadır.

\section{Tablo 5}

Yatay Kesit Bağımlılı̆̆ı Test Sonuçları

\begin{tabular}{|l|l|}
\hline & Value \\
\hline CD Test & $16.49^{*}$ \\
\hline Bias Adjusted LM Test & $47.09^{*}$ \\
\hline
\end{tabular}

* yüzde 1 anlamlılık düzeyini göstermektedir. Boş hipotez yatay kesit bağımlılığı olmaması biçimindedir.

Tablo 5'den izlenebileceği gibi her iki testte de yatay kesit bağımlılığı olmaması biçiminde kurulan temel hipotez reddedilmektedir. Sonuç olarak değişkenler arasında yatay kesit bağımlılığı vardır. Denklemde ve serilerde yatay kesit bağımlılığının olması paneli oluşturan ülkeler arasında da yatay kesit bağımlılığı olduğu anlamına gelmektedir. Bu durum şu şekilde yorumlanmaktadır, ülkelerin herhangi birinde değişkenler üzerinde yaşanacak bir şok etki diğer ülkeleri de etkisi altına alacaktır. $\mathrm{Bu}$ nedenle, bu ülkeler değişkenleri etkisi altına alan, politikalar belirlerken paneli oluşturan diğer ülkelerin uyguladıkları politikaları ve bu ülkelerin refah seviyelerini etkileyen şokları da göz önünde bulundurmalıdırlar. Ayrıca, analizin ilerleyen aşamalarında kullanılacak yöntemler seçilirken yatay kesit bağımlılığını dikkate alan test yöntemlerinin kullanılması gerekmektedir. $\mathrm{Bu}$ nedenle yatay kesit bağımlılığı bulunduktan sonra birim kök incelemesi için yatay kesit bağımlılığını dikkate alan Peseran (2007) tarafından önerilen CIPS birim kök testi kullanılmıştır.

\section{Cips Birim Kök Testi (Cross-Sectionally Im-Pesaranshin)}

$\mathrm{Bu}$ analizde öncelikle serilerin durağanlığının test edilmesi için panel birim kök tesleri kullanılmıştır. Fakat birim kökün var olup olmadığının incelenebilmesi için öncelikle yatay kesit bağımlılığının test edilmesi gerekir bunun için kullanılması geren teslere bir önceki başlıkta yer verilmiştir. Yatay kesit bağımlılığını tespit eden CDLM testi sonucunda yatay kesit bağımlılı̆̆ının olmaması yönünde kurulan temel hipotez reddedilirse, ikinci nesil birim kök teslerinin kullanılması daha doğru, etkin, tutarlı ve güçlü sonuçlara ulaşılmasını sağlamaktadır.

$\mathrm{Bu}$ nedenle serilerin durağanlığını test ettiğimiz 2. nesil birim kök testlerinden, panel ülkelerinin durağanlıklarını bütün olarak sınayan 
durağanlık testi olarak Pesaran (2006)'nın CIPS (Cross-Sectionally Im-PesaranShin) Testi kullanılmıştır. CIPS tahmincisinin uygulanması sonucu ulaşlan test istatistiği değerleri, Pesaran (2006)'daki kritik tablo değerleriyle karşılaștırılarak panel verilerin bütün olarak durağan olup olmadığı test edilebilmektedir. CIPS testi sonuçları Tablo 6'te sunulmaktadır.

\section{Tablo 6}

CiPS Birim Kök Testi Sonuçları

\begin{tabular}{|c|c|c|c|c|}
\hline & \multicolumn{2}{|c}{ Düzey } & \multicolumn{2}{c|}{ Birinci Fark } \\
& Sabit & Sabit + Trend & Sabit & Sabit +Trend \\
\hline LGDP & -1.993 & -2.370 & $-3.555^{*}$ & $-3.630^{*}$ \\
\hline LRD & -1.739 & -2.432 & $-3.557^{*}$ & $-3.785^{*}$ \\
\hline LGDS & -2.090 & -2.149 & $-3.481^{*}$ & $-3.653^{*}$ \\
\hline LHTE & -2.092 & -2.535 & $-4.172^{*}$ & $-4.177^{*}$ \\
\hline
\end{tabular}

Notlar: ${ }^{*},{ }^{* *}$ ve ${ }^{* * *}$ sırasıyla $1 \%, 5 \%$ ve $10 \%$ anlamlılık seviyelerinde boş hipotezin reddedildiğini göstermektedir. CIPS testi için temel hipotez birim kök içermesi biçiminde kurulmaktadır.

Tablo 6'dan izlenebileceği gibi dört değişkende birinci farkı alındıktan sonra durağanlaşmaktadır. Yani I(1)'dir. Serilerin I(1) oldukları tespit edildikten sonra değişkenler arasındaki eşbütünleşme ilişkisinin analizi için yine yatay kesit bağımlılı̆̆ını dikkate alan Westerlund (2008) tarafından önerilen Durbin Hausman eș bütünleșme testi kullanılmıștır. Çıkan sonuçlar ise Tablo 7'de sunulmaktadır.

\section{Westerlund Durbin-Hausman Test}

Durağan olmayan seriler arasında durağan bir ilișkinin varolup olmadığı yani uzun dönemli bir ilișkinin bulunup bulunmadığı eșbütünleșme analizleri ile ele alınmaktadır. Bu nedenle Westerlund (2008) tarafindan geliștirilen "Durbin Hausman Eşbütünleșme Testi" kullanılmıștır. Söz konusu test istatistiği aşağıdaki gibi hesaplanmaktadır:

$D H_{g}=\sum_{i=1}^{n} \widetilde{S}_{i}\left(\widetilde{\varnothing}_{i}-\bar{\varnothing}_{i}\right)^{2} \sum_{t-2}^{T} \hat{e}_{i t-1}^{2}$

Ikinci istatistik olan Durbin Hausman panel istatistiği ise otoregresif parametrelerin homojen olduğunu varsayar ve bu varsayım altında 
sonuç üretir. Söz konusu test istatistiği de aşağıda gösterildiği şekilde hesaplanmaktadır:

$$
D H_{P}=\hat{S}_{n}(\widetilde{\emptyset}-\widehat{\emptyset})^{2} \sum_{i=1}^{n} \sum_{t=2}^{T} \hat{e}_{i t-1}^{2}
$$

Yatay kesit bağımlılığının olduğu ve serilerin durağan olduğu tespit edilen panel veri setinde ekonometrik analizde, eşbütünleșik bir ilişkinin olup olmadığını test etmek için Westerlund (2007) testi uygulanmaktadır. Westerlund (2007) eşbütünleşme testi, bir LM istatistiği testidir, yapısal kırılmayı, yatay kesit bağımlılığını dikkate alan ve doğrusal olmayan serilerde de uygulanabilen bir testtir.

\section{Tablo 7}

Westerlund Durbin-Hausman Test Sonuçları

\begin{tabular}{|l|l|}
\hline & Değer \\
\hline DHg & $1.801^{*}$ \\
\hline DHp & $2.514^{*}$ \\
\hline
\end{tabular}

* yüzde 1 anlamlılık düzeyini göstermektedir. Boş hipotez eş bütünleşme olmaması biçimindedir.

$\% 10=1.28 \% 5=1.645 \% 1=2.333$

Eş bütünleşme analizi; Ar-Ge harcamaları, yurtiçi tasarruflar ve yüksek teknoloji ihracatı ile kişi başına düşen milli gelir arasında eş bütünleşme ilişkisi olduğunu göstermektedir. Eş bütünleşme ilişkisi tespit edildikten sonra Pesaran ve Yamagata (2008) tarafından önerilen eğim heterojenliği testi kullanılarak eğim heterojenliği incelenmiştir. Eğim heterojenliği testinin sonuçları Tablo 7'de sunulmaktadır.

\section{Eğim Heterojenliği (Slope Heterogenetty)}

Panel veri analizinde uygulanacak olan yöntemlerin içeriğini değiştirebilecek olan bir diğer unsur da serilerin homojenliğinin test edilmesidir. Gözlem yapılan gruplar arasında yakın ve benzer ilişkilerin varlığı söz konusu ise homojen bir grubun varlığı, tam tersi bir durum olması durumunda, yani gözlem yapılan gruplar arasında aranılan özellik açısından yakın ve benzer özellikler olmaması halinde ise heterojen bir grubun varlığından söz edilebilir. Serilerin homojenliği de aşağıdaki denklemde belirtildiği şekliyle delta testleri ile sinanmaktadır (Pesaran ve Yamagata, 2008, s. 56): 


$$
\tilde{\Delta}_{a d j}=\sqrt{N} \frac{N^{-1} \tilde{S}-E\left(\widetilde{Z_{i t}}\right)}{\sqrt{\operatorname{Var}\left(\widetilde{Z_{i t}}\right)}}
$$

$\tilde{\Delta}_{\text {adj }}$ şekildedir:

$\mathrm{H}_{0}$ : Homojenlik vardır,

$\mathrm{H}_{1}$ : Heterojenlik vardır

\section{Tablo 8}

Eğim Heterojenliği (Slope Heterogeneity) Test Sonuçları

\begin{tabular}{|l|l|}
\hline & \multicolumn{1}{|c|}{ Value } \\
\hline & $289.2001^{*}$ \\
\hline $\mathbf{( 1 )}$ & $131.7384^{*}$ \\
\hline $\mathbf{( 1 )}$ & $154.4770^{*}$ \\
\hline $\mathbf{1})$ & $20.9230^{*}$ \\
\hline $\mathbf{( 1 )}$ & $1.6647^{* *}$ \\
\hline $\mathbf{2})$ & $14.7929^{*}$ \\
\hline $\mathbf{2})$ & $16.8283^{*}$ \\
\hline $\mathbf{( 2 )}$ & $20.9230^{*}$ \\
\hline$(2)$ & $1.6647^{* *}$ \\
\hline
\end{tabular}

, ** sırasıyla $\% 1$ ve $\% 5$ anlamlılık düzeylerini gösterir. Temel hipotez eğim homojenliği şeklindedir.

Eğim hetorejenliği testleri sonuçları temel hipotez olan eğimin homojen olması durumunun reddedildiğini göstermektedir. Yani modelde eğimin heterojen olduğu ve eğim heterojenliğini dikkate alan tahmincilerin kullanılması gerektiği ortaya çıkmaktadır.

Katsayı tahminleri için modelde hem yatay kesit bağımlılığı hem de eğim hetorejenliği bulunduğu için bu sorunları dikkate alan Dinamik CCEMG tahmincisi kullanılmıştır. Dinamik CCEGME tahmincisi sonuçları Tablo 9'da sunulmaktadır. 
Tablo 9

Dinamik CCEMG Tahmincisi Sonuçları

\begin{tabular}{|c|c|}
\hline $\begin{array}{l}\text { Bağımlı Değişken (Church of Scotland. } \\
\text { General Assembly.) }\end{array}$ & Katsayılar \\
\hline L(GDP) & $0.224^{*}$ \\
\hline LRD & $0.109^{* * *}$ \\
\hline LGDS & $0.000^{* *}$ \\
\hline LHTE & $0.043^{* *}$ \\
\hline
\end{tabular}

* ve ** sırasıyla $\% 1, \% 5$ ve $10 \%$ anlamlılık düzeylerini göstermektedir.

Katsayısılar beklentiler doğrultusunda pozitif ve istatistiksel olarak anlamlı bulunmuştur. Bu katsayıların pozitif ve anlamlı olması yurtiçi tasarruflar, Ar-Ge harcamaları ve yüksek teknoloji ürün ihracatına dayalı büyüme hipotezinin doğruluğunu göstermektedir. Panel Modelde bu örneklem için bulunan sonuçlar şu şekilde yorumlanabilir; Gayri safi milli hasıladan Ar-Ge harcamalarına ayrılan payın \%1 oranında artması kişi başına düşen milli gelirin \% 0.109 oranında artmasına neden olmaktadır. Yurtiçi Tasarruflarda meydana gelen \%1 oranındaki artış kişi başına düşen milli gelirde \%0.100 oranında artışa neden olmaktadır. Yüksek Teknoloji İhracatında meydana gelen \%1'lik artış kişi başına düşen milli gelirde $\% 0.043$ oranında bir artışa neden olmaktadır. Buna göre ülkelerin sürdürülebilir ekonomik büyümelerine en büyük etkiye sahip olan değişkenin Ar-Ge harcamaları olduğu sonucuna varılmıștır.

Türkiye 1975 yılında düşük orta gelir seviyesine ulaşmış ve 2004 yılında ise yüksek orta gelir seviyesine geçmeyi başarmıştır. Yaklaşık 29 yıl alt orta gelir seviyesinde kaldıktan sonra, 2004 yılı itibariyle geçiş yaptığı üst orta gelir grubunda 14 yıldır yer alan Türkiye için elde edilen Dinamik CCEGM sonuçları Tablo 10'da sunulmaktadır; 
Tablo 10

Dinamik CCEGM Modelinden Elde Edilen Türkiye'ye Ait Katsayılar

\begin{tabular}{|c|c|c|c|}
\hline Ülke & Rd & Gds & Hte \\
\hline Türkiye & 0.492527239 & 1.147808241 & 0.062794886 \\
\hline
\end{tabular}

Türkiye'nin Ar-Ge harcamaları katsayısı 0.49 bulunmuştur. Bu sonuç, Türkiye'de Ar-Ge harcamalarında meydana gelen \%1 oranındaki artışın GSYH'nın \%0.49 arttırması biçiminde yorumlanmaktadır. Yurtiçi tasarruf katsayısı 1.147 bulunmuştur. Bu sonuç; yurtiçi tasarruf oranlarında meydana gelen artışın, kişi başına düşen milli gelir üzerinde $\% 1.147$ oranında artışa neden olacağı şeklinde yorumlanmaktadır. Yüksek teknoloji ürün ihracatında meydana gelen \%1 oranında artış ise kişi başına düşen milli gelirin \% 0.062 oranında artmasına neden olmaktadır. Modelde yer alan değişkenlerden yol çıkarak Türkiye'nin orta gelir tuzağından çıkabilmesin de ya da sündürülebilir büyüme hedefini gerçekleştirebilmesinde en büyük etkiye sahip faktörün yurtiçi tasarrufların artırılmasına yönelik politikalar olduğu görülmektedir.

Türkiye'nin Ar-Ge harcamaları katsayısı 0.49 bulunmuştur. Bu sonuç, Türkiye'de Ar-Ge harcamalarında meydana gelen \%1 oranındaki artışın GSYH'nın \%0.49 arttırması biçiminde yorumlanmaktadır. Yurtiçi tasarruf katsayısı 1.147 bulunmuştur. $\mathrm{Bu}$ sonuç; yurtiçi tasarruf oranlarında meydana gelen artışın, kişi başına düşen milli gelir üzerinde \% 1.147 oranında artışa neden olacağı şeklinde yorumlanmaktadır. Orta gelir tuzağı içinde yer alan Türkiye'nin kişi başına düşen milli gelirine en çok etki eden değişken yurtiçi tasarruflardır.

\section{Sonuç}

Ülkelerin sürdürülebilir ekonomik büyüme hedefine ulaşabilme arzusu her dönem var olmakla birlikte bu hedefe ulaşmakta izlenecek yol haritası farklılık göstermektedir. Öğleki çağın gerekliliklerinin gerisinde kalan, teknolojik gelişmeleri takip edemeyen, üretim kapasitesini artıramayan, değişen istek ve ihtiyaçlara yönelik mal ve hizmet üretemeyen, nitelikli insan gücüne ve yapısal reformlara oldukça ihtiyaç duyulan orta gelirli ülkeler, az gelişmiş ülkeler ile düşük ücretli standart imalat sanayi ürünleri üretiminde rekabet edememekte diğer taraftan inovasyon temelli büyüyen üst gelir grubu ülkeleri yakınsamakta ise zorlanmaktadırlar. Dolayısıyla orta gelir tuzağında yer alan ülkeler 
coğrafi konumları, hammadde kaynakları, genç nüfus oranları gibi birçok faktöre bakılmaksızın yüksek gelirli ülkeler grubuna geçişte zorlanmakta ve bulunduğu refah sınırını ise uzun yıllar aşamamaktadırlar.

Bu çalışmada elde edilen sonuçlar ıșığında orta gelirli ülkelerin refah seviyelerini artırmada en önemli faktör, yatırımların yurtiçi tasarruflar ile desteklenmesi ve Ar-Ge harcamalarına ayrılan ödeneklerin artırılmasının gerekliliğidir. Ancak buyolla küresel rekabetin gerisindekalan; inovasyona yönelik politikalar üretemeyen, inovasyon yaratmaya yönelik yatırımlar yapmakta zorlanan, dolayısıyla enformasyon ve iletişim teknolojilerinin gerisinde kalan az gelişmiş ve gelişmekte olan ülkeler orta gelir eşiğini aşmayı başarabileceklerdir.

Türkiye 1975 yılında düşük orta gelir seviyesine ulaşmış ve 2004 yılında ise yüksek orta gelir seviyesine geçmeyi başarmıştır. Yaklaşık 29 yıl alt orta gelir seviyesinde kaldıktan sonra, 2004 yılı itibariyle geçiş yaptığı üst orta gelir grubunda ise 14 yıldır yer almaktadır. Bu bağlamda orta gelirli diğer ekonomiler ile benzer olan tüketim odaklı büyüme stratejilerinden inovatif yatırımlara ve ihracat odaklı büyümeye geçişin kontrollü olarak sağlanabilmesi gerekmektedir. Bilgi faktörünün, patentin ömrü boyunca "artan getiriye sahip olması" bilginin girdi olarak kullanıldığı sanayilerde toplam faktör verimliliğinde artışa neden olmaktadır. Ancak bilginin girdi olarak kullanıldığı sanayiler, Ar-Ge faaliyetlerine çok uzun yıllardır yatırım yapan ve böylelikle yüksek teknoloji ürün ihracatını ve toplam faktör verimliliğini artırabilmeyi başarmış üst gelir grubunda yer alan ülkelerdir. Orta gelirli ülkelerde ise aynı șekilde verimliliğin ve sürdürülebilir büyümenin sağlanabilmesinde, analiz sonuçlardan da anlaşllabileceği üzere öncelikli hedef yurtiçi tasarrufların artırılabilmesidir. Böylelikle Ar-Ge ve İnovasyona yönelik yapılacak yatırımlar yurtiçi kaynaklarla finanse edilebilecektir. Bu nedenle sadece halkın tasarruf yapmasının yanı sıra kamunun ve halkın eş güdümlü olarak tasarrufa yöneltilmesi ve en önemlisi birçok orta gelirli ülkenin uyguladığı tüketim odaklı büyüme politikalarından uzaklaşllarak, katma değeri yüksek mal ve hizmet üretimi ile ithalatı azaltıp ihracat gelirlerini artırmaya özen göstermek gerekmektedir. Yerli üretim ve yerli mal tüketimi teşvik edilerek ithal ürünler daha yüksek oranda vergilendirilmelidir. Sonuç olarak, hızla yayılan teknolojik dönüşüm ile birlikte nitelikli insan gücüne olan ihtiyaç giderek artmakta ve bu ihtiyacın giderilebilmesinde eğitim sistemine yönelik reformlar zorunlu olmaktadır. Bu nokta da gelecek çalışmalarda, orta gelir tuzağından çıkmayı başarmış ülkelerin bu başarılarının temelindeki makroekonomik etmenler araştırılacak, inovasyon temelli yatırımların önemine ve Endüstri 4.0'a geçişle gün geçtikçe artan nitelikli 
insan gücüne ihtiyacın ortaya çıkaracağı olumlu ve olumsuz sonuçlara yer verilecektir.

Yatırımlara ve ihracat odaklı büyümeye geçişin kontrollü olarak sağlanabilmesi gerekmektedir. Bu nokta da gelecek çalışmalarda, orta gelir tuzağından çıkmayı başarmış ülkelerin bu başarılarının temelindeki makroekonomik etmenler araştırılacak, inovasyon temelli yatırımların önemine ve Endüstri 4.0'a geçişle gün geçtikçe artan nitelikli insan gücüne ihtiyacın ortaya çıkaracağı olumlu ve olumsuz sonuçlara yer verilecektir.

\section{Kaynakça / References}

Abiad, A., Debuque-Gonzales, M. and Sy, A. L. (2018). The evolution and impact of infrastructure in middle-income countries: anything special?. Emerging Markets Finance and Trade, 54(6), 1239-1263.

Agenor, P. and Canuto, O. (2012). Middle income growth traps. Policy Research Working Paper Series 6210. Washington: World Bank.

Alptekin, V., Kasa, Ö. G. H. ve Uygun, Ö. G. E. (2018). Yurtiçi tasarruflar ile ekonomik büyüme arasindaki iliş̧ki: Türkiye örneği. International Journal of Academic Value Studies, 4(20), 621-630.

Baltagi, B. H. and Li, Q. (1990). A Lagrange multiplier test for the error components model with incomplete panels. Econometric Reviews, 9(1), 103-107.

Blanchard, O. and Giavazzi, F. (2002). Current account deficits in the euro area: the end of the Feldstein-Horioka puzzle? Brookings Papers on Economic Activity, 2002(2), 147-186.

Bulman, D., Eden, M. and Nguyen, H. (2017). Transitioning from low-income growth to high-income growth: is there a middle-income trap? Journal of the Asia Pacific Economy, 22(1), 5-28.

Breusch, T. S. and Pagan, A. R. (1980). The Lagrange multiplier test and its applications to model specification in econometrics. The Review of Economic Studies, 47(1), 239-253.

De Hoyos, R. and Sarafidis, V. (2006). Testing for cross-sectional dependence in panel-data models. Stata Journal, 6(4), 482-496.

Duramaz, S., Taş, T. ve Yılmaz, K.Ç. (2017). Yapısal kırılmalar altında satın alma gücü paritesinin geçerliliği: Türkiye örneği. 3. International Congress on Economics and Business 'New Economic trends and Business Opportunities' bildiri kitabı içinde (s. 213-216). Manisa Celal Bayar Üniversitesi. 
Egawa, A. (2013). Will income inequality cause a middle-income trap in Asia? Bruegel Working Paper.

Eichengreen, B., Park, D. and Shin, K. (2013). Growth slowdowns redux: New evidence on the middle-income trap (No. w18673). National Bureau of Economic Research.

Felipe, J., Abdon, A. and Kumar, U. (2012). Tracking the middle-income trap: What is it, who is in it, and why? Levy Economics Institute, Working Paper No. 715.

Gill, I. S. and Kharas, H. (2007). An East Asian renaissance: Ideas for economic growth. The World Bank.

Greenwood, J. and Smith, B. D. (1997). Financial markets in development, and the development of financial markets. Journal of Economic Dynamics and Control, 21(1), 145-181.

Gill, Indermit S. and Kharas, H. (2007). An East Asian Renaissance: Ideas for economic growth. Washington D.C.: World Bank.

Gore, C. (2017). Late industrialisation, urbanisation and the middle-income trap: an analytical approach and the case of Vietnam. Cambridge Journal of Regions, Economy and Society, 10(1), 35-57.

Kim, J., and Park, J. (2018). The role of total factor productivity growth in MiddleIncome Countries. Emerging Markets Finance and Trade, 54(6), 1264-1284

Ha, J. and Lee, S. H. (2016). Demographic dividend and Asia's economic convergence towards the US. The Journal of the Economics of Ageing, 8, 28-41.

Im, K. S., Pesaran, M. H. and Shin, Y. (2003). Testing for unit roots in heterogeneous panels. Journal of econometrics, 115(1), 53-74.

Liu, X., Schwaag, S. S., Tagscherer, U. and Chang, A. Y. (2017). Beyond catchup-can a new innovation policy help China overcome the middle income trap? Science and Public Policy, 44(5), 656-669.

Lin, J. Y. (2017). Industrial policies for avoiding the middle-income trap: a new structural economics perspective. Journal of Chinese Eonomic and Business Studies, 15(1), 5-18.

Nungsari, A. R. and Zeufack, A. G. (2009). Escaping the middle-income trap. Chapter in Readings on Development: Malaysia 2057, Khazanah Nasional Berhad.

OECD (2014) Perspectives on global development: Boosting productivity to meet the middle-income challenge. Paris: OECD. 
O'Connell, P. G. (1998). The overvaluation of purchasing power parity. Journal of International Economics, 44(1), 1-19.

Paus, E. (2012). Confronting the middle income trap: insights from small latecomers. Studies in Comparative International Development, 47(2), 115-138.

Pesaran, M. H. and Smith, R. (1995). Estimating long-run relationships from dynamic heterogeneous panels. Journal of Econometrics, 68(1), 79-113.

Pesaran, M. H. (2004). General diagnostic tests for cross section dependence in panels.

Pesaran, M. H. (2007). A simple panel unit root test in the presence of crosssection dependence. Journal of Applied Econometrics, 22(2), 265-312.

Pesaran, M. H. and Yamagata, T. (2008). Testing slope homogeneity in large panels. Journal of Econometrics, 142(1), 50-93.

Pesaran, M. H., Ullah, A. and Yamagata, T. (2008). A bias-adjusted LM test of error cross-section independence. The Econometrics Journal, 11(1), 105-127.

Spence, M. (2011). The next convergence: The future of economic growth in a multispeed world. New York: Farrar, Straus and Giroux.

Sarafidis, V., Yamagata, T. and Robertson, D. (2009). A test of cross section dependence for a linear dynamic panel model with regressors. Journal of Econometrics, 148(2), 149-161

Summers, R. and Heston, A. (1991). The Penn World Table (Mark 5): An expanded set of international comparisons, 1950-1988. The Quarterly Journal of Economics, 106(2), 327-368.

Taş, T., Alptekin, V. and Yılmaz, K. Ç. (2017). The stability of money demand under the structural breaks in Turkey. Journal of Current Researches on Business and Economics, 7(1), 265-280.

Tran, V. T. (2013). The middle-income trap: Issues for members of the Association of Southeast Asian Nations.

Yilmaz, K. C.. ve Alptekin, V. (2018). Denge döviz kurundan sapma ve sapmanın ekonomik büyüme üzerindeki etkisi: Feer yaklaşımı. Yönetim ve Ekonomi, 25(2), $427-450$

Westerlund, J. (2008). Panel cointegration tests of the Fisher effect. Journal of Applied Econometrics, 23(2), 193-233. 


\section{Summary}

The middle income trap describes the countries that have not been able to accomplish the sustainable economic growth and have been stuck in the level of income per capita for many years. The concept first introduced by Gill and Kaharas (2007) who are World Bank employees defines the countries that are caught in the middle income trap as the countries that can not compete with the underdeveloped countries in the low-paid standard manufacturing industry products while the countries having difficulty in converging with the ones in the upper income group developing innovatively. Therefore, the countries in the middle income trap can not exceed many years to high income countries level regardless of many factors such as geographical conditions, raw material resources, young population rates. In this study, it has been examined that the reasons of middle income trap and current literature. The countries located in OECD have been analyzed by using savings rate, R\&D expenditures and high technology export data and investigated effects on sustainable economic growth. The results were evaluated for selected 20 OECD countries. These OECD countries in the model are respectively; Turkey, USA, Italy, South Korea, Germany, France, Iceland, Denmark, Austria, Israel, Canada, Britain, the Czech Republic, Hungary, Poland, Greece, Latvia, Slovakia, Portugal and Japan. Because of the R \& D expenditures data has been published as an annually, other independent variables data set was also used as annually. By the way in his study, R \& D expenditures are effective on innovation and technological developments that form the basis of Industry 4.0, and in this way inferences have been made on the effect of the middle income trap on productivity. The effects of high technology product exports supported by R \& D expenditures in meeting the varying demands and needs for a similar purpose were also discussed. The supporting of investments with domestic resources is very important for developing countries growth therefore it was appropriate to add domestic savings as an independent variable into the model.

The variables in question have been analysed by applying the dynamic CCEGM model in the new generation panel data models applied in the event of that gradient index is heterogeneous and takes cross sectional dependence into consideration. As a result of the panel data formed by the data of 1995-2015 of 20 countries that are OECD members, positive results of variables have been obtained as expected. The obtained results can be interpreted in the following way; when the share allocated from GDP to $\mathrm{R} \& \mathrm{D}$ expenditures increases by $1 \%$, the per capita income increases by $0.109 \%$. The increase in domestic savings by $1 \%$ leads an increase of 
$0.100 \%$ per capita income and the increase in high technology exports by $1 \%$ leads to an increase of $0.043 \%$ per capita income. Accordingly, it is concluded that the variable that has the greatest effect on the sustainable economic growth of the countries is R \& D expenditures.

As a middle income country Turkey, reached low middle income level in 1975 and achieved a high middle income level 2004. Approximately 15 years after of this success Turkey is still in the high middle income countries and it has been almost same per capita income level. When we analyze our independent variables effects on GDP per capita with Dynamic CCEMG estimator for Turkey we achieved this results:

Coefficient of R \& D expenditures were found 0.49 and that is interpreted as if increase of $\mathrm{R} \& \mathrm{D}$ expenditure at the rate of $\% 1$, GDP per capita will raising \% 0.49,

Coefficient of domestic savings were found 1.147 and that is interpreted as if increase of domestic savings at the rate of \% 1, GDP per capita will raising \% 1.147,

Coefficient of high technology exports was found 0.062 and that is interpreted as if increase of high technology exports at the rate of $\% 1$, GDP per capita will raising \% 1.147.

According to the results obtained in this study, the most important factor in increasing the welfare levels of middle-income countries is to support investments with domestic savings and to increase the appropriations allocated for R \& D expenditures. Developing countries that can achieve these goals will not to fall behind the global competition and will produce policies for innovation, to make innovative investments, thus to capture information and communication technologies and overcome the middle income trap. Export revenues that can be increased in this way will help reduce the current account deficit and the need for external borrowing. 